\title{
Electrochemical Sensing Platforms for HER2-ECD Breast Cancer Biomarker Detection
}

\author{
Maria Freitas
}

Henri P. A. Nouws

Cristina Delerue-Matos

\begin{abstract}
Screening and early diagnosis are crucial to increase the success of cancer patients' treatments and improve the survival rate. To contribute to this success, distinct electrochemical immunosensing platforms were developed for the analysis of the ExtraCellular Domain of the Human Epidermal growth factor Receptor 2 (HER2-ECD) through sandwich assays on nanomaterial-modified screen-printed carbon electrodes (SPCEs). The most promising platforms showed to be SPCEs modified with (i) gold nanoparticles (AuNPs) and (ii) multiwalled carbon nanotubes combined with AuNPs. The antibody-antigen interaction was detected using a secondary antibody labelled with alkaline phosphatase and 3-indoxyl phosphate and silver ions as the enzymatic substrate. The electrochemical signal of the enzymatically generated metallic silver was recorded by linear sweep voltammetry. Under the optimized conditions, linear calibration plots were obtained between 7.5 and $50 \mathrm{ng} / \mathrm{mL}$ and the total assay time was $2 \mathrm{~h} 20 \mathrm{~min}$, achieving LODs of $0.16 \mathrm{ng} / \mathrm{mL}$ (SPCE-MWCNT/AuNP) and $8.5 \mathrm{ng} / \mathrm{mL}$ (SPCE-AuNP), which are well below the established cut-off value of $15 \mathrm{ng} / \mathrm{mL}$ for this cancer biomarker.
\end{abstract}

\section{Introduction}

Breast cancer, one of the major life-threatening diseases in woman, is still one of the leading causes of oncological deaths $\underline{1}$. Diagnostic techniques for its detection are in constant development but are yet far from ideal. Currently medical strategies for screening and early detection are based on imagiology tools, namely mammography. Although detection is usually achieved with high efficiency, it only allows the visualization of the tumour and cannot predict its biological behaviour and evolution $\underline{2}$, 3. Nevertheless, the evolution of clinical methods for effective detection of breast cancer along with the development of non-invasive and low-cost in situ techniques can improve survival rates and allow personalized patient follow-up $\underline{2}, \underline{4}$. These non-invasive methods are a prominent alternative not only regarding response time but also to minimize the patients' suffering. For this purpose, biosensors have been developed because they provide fast analysis and specific recognition. Therefore, their development is in continuous expansion and they have widely been applied in point-of-care detection $\underline{4}, \underline{5}$. Current innovations in the field of biosensing lead to accurate results in the analysis of 
tumour biomarkers in patients' biological fluids such as serum, plasma, whole blood, urine, etc. A tumour biomarker is a substance or process indicative of the presence of cancer in the body $\underline{6}$. Breast cancer biomarkers can be divided into prognostic, therapeutic and diagnostic, and can be detected according to the stage of the cancer $\underline{7}$. Among the variety of biomolecules that are approved as tumour biomarkers and accepted for diagnosis by medical and clinical teams, there are many biological fluid-based biomarkers of interest for the development of electrochemical biosensors. The main protein breast cancer biomarkers for non-invasive clinical tests are the Human Epidermal growth factor Receptor 2 (HER2, ErbB2 or CD340), Cancer Antigen 15-3 (CA 15-3) and Carcinoembryonic Antigen (CEA). In addition, Circulating Tumour Cells (CTCs) can also provide prognostic or predictive information $\underline{8}, \underline{9}$. In serum analysis biomarkers that shed extracellular domains in the peripheral blood (e.g. HER2) are important analytes that can be used as a source of information on the status of the tumour. HER2-ECD is a protein breast cancer biomarker that presents serum levels below $15 \mathrm{ng} / \mathrm{mL}$ for healthy individuals and can be important for patients' screening and early detection. HER2 is overexpressed in 20-30\% of invasive breast cancer and HER2-positive breast cancer is particularly more aggressive than others $\underline{7}-\underline{9}$.

A few electrochemical immunosensing strategies for the detection of HER2 in serum have been reported. These strategies are generally based on the modification of the electrode surface with nano- or micromaterials that can provide improved performances like the promotion of electron transfer, signal amplification and the decrease of the limit of detection. Furthermore, the use of small-size transducers, the reasonably short assay times and the low reagent/sample volumes are key features for the development of point-ofcare devices. Marques et al. (2014) developed a sandwich-type assay on screen-printed carbon electrodes (SPCEs) which were nanostructured with gold nanoparticles (AuNP) to efficiently immobilize anti-HER2-ECD capture antibodies through chemisorption 10 . In a different approach Ravalli et al. developed a label-free impedimetric biosensor based on the immobilization of a terminal cysteine-modified affibody on gold nanostructured graphite screen-printed electrodes. AuNPs were used in these studies to enhance the capture antibody's immobilization and to retain its immunoactivity on the electrode 11 . Furthermore, the use of nanomaterials, with excellent and reliable physicochemical properties, in the sensor's construction increases the electrode's surface area with a subsequent increase of sensitivity $\underline{12}$. Arkan et al. proposed an immunosensor based on multiwalled carbon nanotubes (MWCNTs) and AuNPs contained in a carbon ionic liquid electrode (CILE). Pre-synthesized AuNPs were grown on the MWCNT-CILE surface through electrodeposition, to form AuNP/MWCNT-CILE, which is a suitable surface for antibody attachment $\underline{13}$. In a distinct approach, Emami et al. employed magnetic iron nanoparticles for efficient antibody immobilization on an electrode surface that was previously modified with AuNPs/3-mercaptopropionic acid/cysteamine/poly(ethylene glycol)-maleimide-3-aminopropyltrimethoxysilane $\underline{14}$. Moreover, in an analogous but simpler methodology, Shamsipur et al. reported the use of 3aminopropyltrimethoxysilane coated magnetite nanoparticles combined with an antibody (antiHER2/APTMS-Fe ${ }_{3} \mathrm{O}_{4}$ NPs) as a platform for efficient HER2 detection $\underline{15}$. The easy 
manipulation, washing and collection of the magnetic nanoparticles using simple magnets or magnetic bars are major advantages compared to non-magnetic assays, reducing crossreactivity and matrix effects. Efficient bioconjugation is largely achieved by using magnetic particles comprising a magnetite core $\left(\mathrm{Fe}_{3} \mathrm{O}_{4} \mathrm{MNPs}\right)$ with a non-magnetic coating $\underline{5}$. Al-Khafaji et al. and Ilkhani et al. used magnetic beads functionalized with Protein A to improve the affinity interaction between the biomolecules and to construct faster electrochemical bioassays $\underline{16}, \underline{17}$. Eletxigerra et al. developed a magnetoimmunosensor based on carboxylic acid-modified magnetic beads. Horseradish peroxidase-labelled secondary antibodies were used and detection was performed through amperometry using the hydroquinone (HQ) $/ \mathrm{H}_{2} \mathrm{O}_{2}$ system $\underline{18}$. Recently, Tallapragada et al. proposed a sandwich-type immunosensor based on the biotin-avidin chemistry for accurate detection of HER2 by using home-made SPEs $\underline{19}$. Although unmodified electrodes were also used for the sensor construction, the total assay time was longer than for the previously reported electrochemical immunosensors.

In this work distinct sensing platforms were studied for the detection of HER2-ECD: (i) SPCEs modified with AuNP, graphene, single- or multiwalled carbon nanotubes (SWCNT, MWCNT) and (ii) SPCEs modified with graphene, SWCNT- or MWCNT in combination with AuNPs, forming hybrid nanostructures. These approaches combined the advantages of the nanomaterials' biocompatibilities and the high binding affinity. The use of carbon nanomaterials allows better coverage of the SPCEs and the electrodeposition of the gold nanoparticles provides a large accessible surface area for effective antibody immobilization. The sensing platforms were characterized by scanning electron microscopy (SEM) and the electrochemical signals were recorded by linear sweep voltammetry (LSV). The detection of the antibody-antigen interaction in the sandwich assay was possible by using a secondary antibody labelled with alkaline phosphatase; the electrochemical signal was generated through the oxidation of enzymatically deposited metallic silver (a mixture of 3-indoxyl phosphate (enzymatic substrate) and silver ions). In this study the use of different carbon nanomaterials, and their combination with AuNPs, with the above-mentioned detection strategy for the detection of HER2-ECD is reported for the first time.

\section{Experimental}

\subsection{Instrumentation}

The electrochemical measurments were carried out using a potentiostat/galvanostat (Autolab PGSTAT101, Metrohm Autolab) controlled by the NOVA software package (v.1.9; Metrohm Autolab). Screen-printed carbon electrodes (SPCE, DRP-110) and a specific connector (DRP-CAC) to interface the electrodes and the potentiostat/galvanostat were supplied by DropSens. The SPCEs consisted of working $(\mathrm{d}=4 \mathrm{~mm})$ and counter electrodes made of carbon inks and a silver pseudoreference electrode. All the electrodes were discarded after use. The SEM images were obtained by using FEI Quanta 400FEG ESEM/EDAX Genesis X4 M equipment, at the "Centro de 
Materiais da Universidade do Porto (CEMUP)". The histograms were obtained using SPSS software, version 20.0 (SPSS Inc., Chicago, Illinois).

\subsection{Reagents}

Albumin from human serum (HSA), albumin from bovine serum (BSA), $\beta$-casein from bovine milk, reduced graphene oxide (rGO), carboxylic acid functionalized multiwalled carbon nanotubes (MWCNT-COOH), carboxylic acid functionalized single-walled carbon nanotubes (SWCNT-COOH), 3-indoxyl phosphate (3-IP), N,Ndimethylformamide (DMF), ethanolamine, hydrochloric acid, magnesium nitrate hexahydrate, nitric acid, streptavidin-alkaline phosphatase (S-AP) from Streptomyces avidinii, human serum (from male AB clotted whole blood), tetrachoroauric(III) acid and tris(hydroxymethyl)aminomethane (Tris), were obtained from Sigma-Aldrich. Silver nitrate was purchased from Alfa Aesar. Rabit IgG monoclonal anti-human-HER2-ECD (clone 002) antibody (capture antibody), mouse IgG2a monoclonal biotinylated antihuman-HER2-ECD (clone 8B5DAC1) antibody (detection antibody), and a recombinant HER2-ECD protein (antigen) were obtained from Sino Biological Inc.

Ultra-pure water (resistivity $=18.2 \mathrm{M} \Omega \mathrm{cm}$ ) was used and was obtained from a Millipore (Simplicity 185) water purification system. The tetrachloroauric(III) acid solution (0.10 $\mathrm{mM}$ ) for the electrodeposition of AuNPs was prepared in $0.1 \mathrm{M} \mathrm{HCl}$. Working solutions of the capture (C) and detection (D) antibodies and the antigen were prepared in $0.1 \mathrm{M}$ Tris- $\mathrm{HNO}_{3} \mathrm{pH} 7.4$ (buffer 1). The S-AP solutions were prepared in $0.1 \mathrm{M}$ Tris- $\mathrm{HNO}_{3} \mathrm{pH}$ 7.4 containing $1 \%$ BSA (buffer 2$)$. The solution containing 3 -IP $\left(1 \times 10^{-3} \mathrm{M}\right)$ and silver nitrate $\left(4 \times 10^{-4} \mathrm{M}\right)$ was prepared in $0.1 \mathrm{M}$ Tris- $\mathrm{HNO}_{3} \mathrm{pH} 9.8$ containing $\mathrm{Mg}\left(\mathrm{NO}_{3}\right)_{2}$ $\left(2 \times 10^{-2} \mathrm{M}\right)$ (buffer 3$)$ and stored at $4{ }^{\circ} \mathrm{C}$ protected from light. All the buffers and solutions were prepared daily.

\subsection{Sensor/Assay Development and Procedure}

Scheme 1 elucidates the different steps of the used sandwich assay.
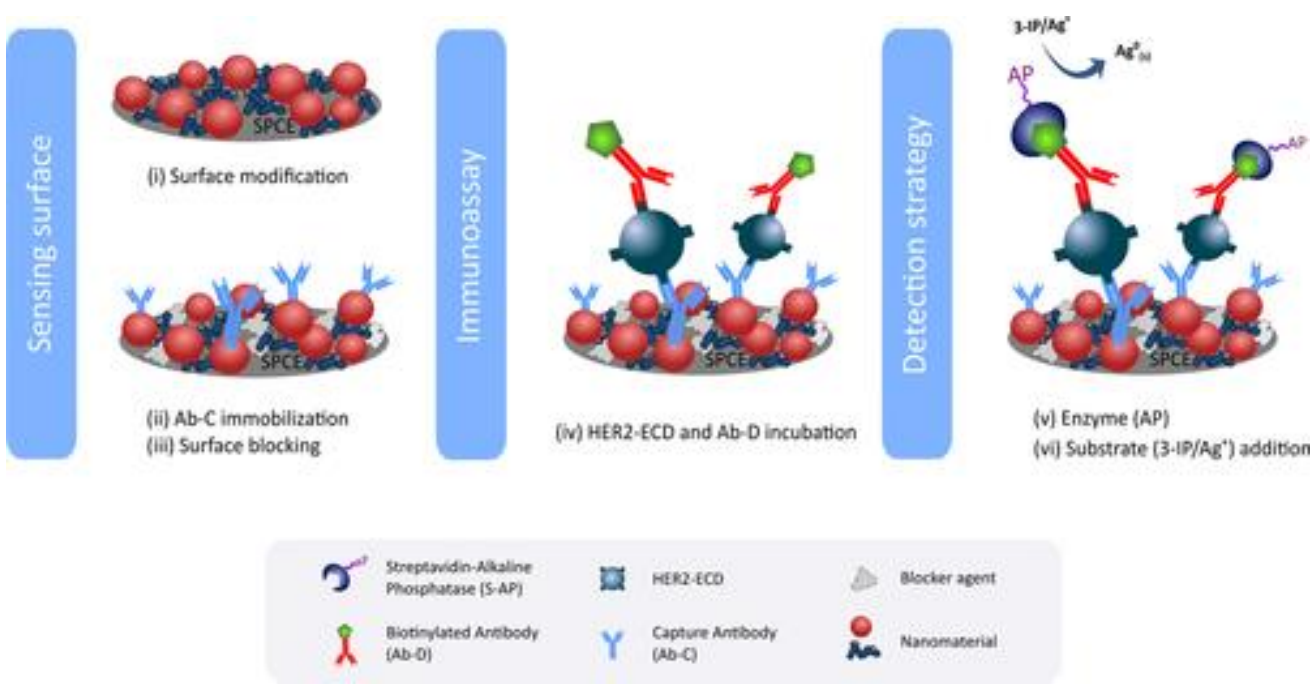


\section{Scheme 1}

Schematic representation of the electrochemical immunoassay.

\subsubsection{Surface Modification}

Several SPCE-based immunosensors were tested using different nanomaterials: rGO, SWCNT-COOH, MWCNT-COOH and AuNPs and combinations of these materials.

For the carbon nanotubes, (i) the surface of the SPCE was modified by dropping a $1-\mu \mathrm{L}$ aliquot of an $\mathrm{rGO}$, SWCNT-COOH or MWCNT-COOH suspension (dispersed in DMF) on the working electrode (WE) of the SPCE which was then dried for 5 minutes at $50^{\circ} \mathrm{C}$.

The modification of the WE (with or without the carbon nanomaterials) with AuNPs was carried out by electrodeposition of gold from $40 \mu \mathrm{L}$ of a $0.10 \mathrm{mM}\left[\mathrm{AuCl}_{4}\right]^{-}$(in $0.1 \mathrm{M}$ $\mathrm{HCl})$ solution according to the procedure described by Martínez-Paredes et al.: first a constant current $(-100 \mu \mathrm{A})$ was applied for $240 \mathrm{~s}$, and subsequently a constant potential $(+0.1 \mathrm{~V})$ was applied for $120 \mathrm{~s} \underline{20}$. The obtained AuNP-modified electrodes were rinsed with water and dried with nitrogen before use.

\subsubsection{Capture Antibody Immobilization}

The immobilization of the capture antibody on the modified SPCE surfaces was performed based on a previous work: (ii) incubation of the SPCE with $10 \mu \mathrm{L}$ of the capture antibody solution (optimized concentration: $25 \mu \mathrm{g} / \mathrm{mL}$ ), overnight at $4{ }^{\circ} \mathrm{C}$ in a humidified chamber. Then the SPCE was washed with buffer 1 before (iii) blocking the free surface sites with $\beta$-casein $(2 \%(\mathrm{~m} / \mathrm{V})$ in buffer $1,40 \mu \mathrm{L}, 30 \mathrm{~min}) \underline{10}$.

\subsubsection{Immunoassay}

The optimized assay consisted of the following steps: after washing with buffer 1, (iv) a previously prepared mixture ( $5 \mathrm{~min}$ before use) containing the detection antibody ( 2 $\mu \mathrm{g} / \mathrm{mL})$, HER2-ECD and BSA $0.5 \%(\mathrm{~m} / \mathrm{V})$ was added $(40 \mu \mathrm{L})$ and left to incubate for 30 min. The washing step was then repeated with buffer 1 , and (v) an aliquot (40 $\mu \mathrm{L})$ of SAP solution $\left(5 \times 10^{-10} \mathrm{M}\right)$ was added for $60 \mathrm{~min}$. Subsequently, a washing step was carried out firstly with buffer 1 , and then with buffer 3 .

For the electrochemical measurements, (vi) a $40-\mu \mathrm{L}$ aliquot of the mixture containing the enzymatic substrate $\left(3-\mathrm{IP}, 1.0 \times 10^{-3} \mathrm{M}\right)$ and silver nitrate $\left(4.0 \times 10^{-4} \mathrm{M}\right)$ was placed on the SPCE and after $20 \mathrm{~min}$ the electrochemical signal was obtained by LSV using the following parameters: potential range: $-0.03 \mathrm{~V}-+0.4 \mathrm{~V}$; scan rate: $50 \mathrm{mV} / \mathrm{s}$.

\subsection{Sample Preparation}


Male human serum was stored at $-20{ }^{\circ} \mathrm{C}$ and was used as obtained, i. e. serum samples were spiked with HER2-ECD at different concentrations and analysed without further treatments. The electrochemical measurements were performed using the abovementioned conditions.

\section{Results and Discussion}

\subsection{Sensor/Assay Optimization}

\subsubsection{Antibody Concentrations}

The immobilization of the capture antibody on the sensor's surface and the detection approach are some of the key features to guarantee the adequate performance of immunosensors. According to a previously reported immunosensor for HER2-ECD detection developed in our group $\underline{10}$, AuNPs constitute a good nanomaterial to be used for immobilization through chemisorption of monoclonal anti-human HER2-ECD antibodies $(\mathrm{Ab}-\mathrm{C})$. This allowed stable immobilization of the antibodies and led to a high sensitivity. In the present study the same procedure was adopted, and the $\mathrm{Ab}-\mathrm{C}$ and $\mathrm{Ab}-$ $\mathrm{D}$ concentrations were studied using SPCE-AuNP and the following conditions: $\mathrm{Ab}-\mathrm{C}$ : 10 and $25 \mu \mathrm{g} / \mathrm{mL}$; casein: $2 \%(\mathrm{~m} / \mathrm{V})$; HER2-ECD: 0 and $50 \mathrm{ng} / \mathrm{mL}$; BSA: $0.5 \%(\mathrm{~m} / \mathrm{V})$; Ab-D: 0.5 ; 1 and $2 \mu \mathrm{g} / \mathrm{mL}$; S-AP: $2.0 \times 10^{-10} \mathrm{M}$ with BSA $1 \%(\mathrm{~m} / \mathrm{V})$. The obtained peak current intensities are presented in Figure 1(a). As can be observed, the lowest $\mathrm{Ab}-\mathrm{C}$ concentration $(10 \mu \mathrm{g} / \mathrm{mL})$ led to the lowest peak current intensities and the increase of the $\mathrm{Ab}-\mathrm{D}$ concentration led to an increase of the electrochemical signal. However, the results also showed that the peak current intensity was similar when the highest Ab-D concentration $(2 \mu \mathrm{g} / \mathrm{mL})$ was used for both $\mathrm{Ab}-\mathrm{C}$ concentrations (10 and $25 \mu \mathrm{g} / \mathrm{mL})$, revealing the importance of the $\mathrm{Ab}-\mathrm{D}$ concentration on the immunosensor's performance. The result can be explained based on the high amount of S-AP that binds to the detection antibody (Ab-D), leading to the signal amplification. Although a good result was achieved with the combination of $\mathrm{Ab}-\mathrm{C} 10 \mu \mathrm{g} / \mathrm{mL}$ and $\mathrm{Ab}-\mathrm{D} 2 \mu \mathrm{g} / \mathrm{mL}$, the best performance was obtained when $\mathrm{Ab}-\mathrm{C} 25 \mu \mathrm{g} / \mathrm{mL}$ and $\mathrm{Ab}-\mathrm{D} 2 \mu \mathrm{g} / \mathrm{mL}$ were used. Therefore, these concentrations were chosen to proceed with the optimization of the immunoassay. 
(a)

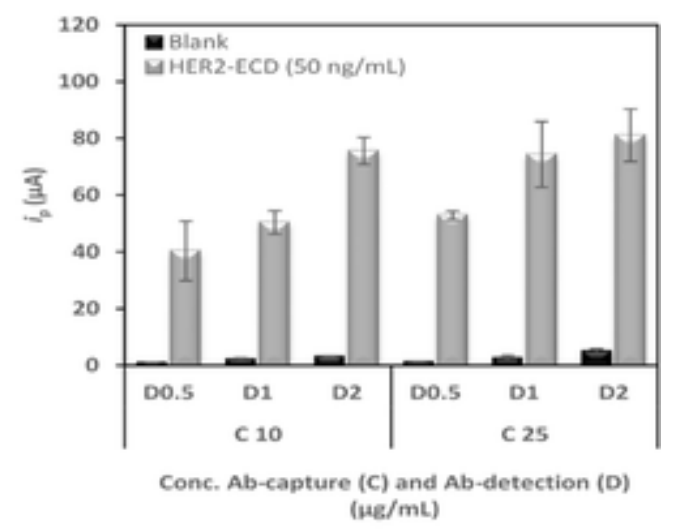

(b)

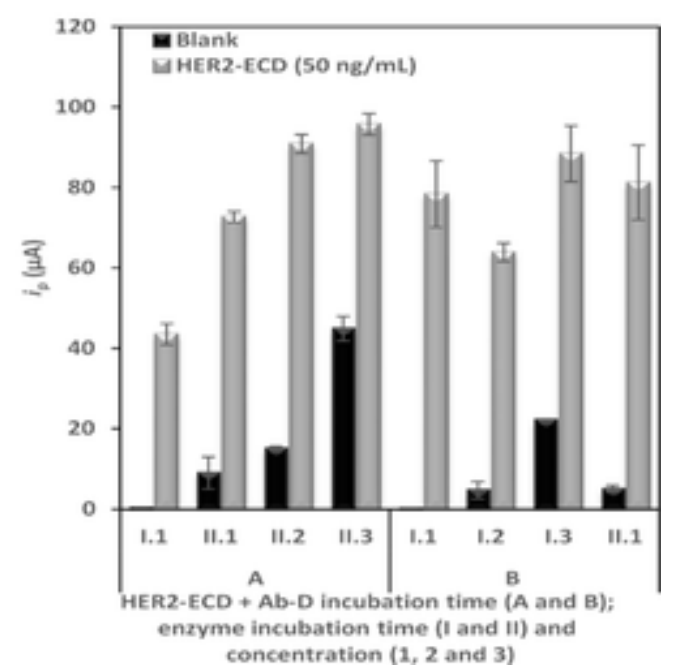

Figure 1

Optimization of (a) $\mathrm{Ab}-\mathrm{C}$ and $\mathrm{Ab}-\mathrm{D}$ concentrations and (b) incubation time of HER $2+A b-D(A-30 \mathrm{~min}$ and $B-60 \mathrm{~min})$, enzyme incubation time (I - $30 \mathrm{~min}$ and II $60 \mathrm{~min})$ and concentration $\left(1-2 \times 10^{-10} \mathrm{M} ; 2-5 \times 10^{-10} \mathrm{M}\right.$ and $\left.3-1 \times 10^{-9} \mathrm{M}\right)$. (Ab-C $(25$ $\mu \mathrm{g} / \mathrm{mL}), \mathrm{Ab}-\mathrm{D}(2 \mu \mathrm{g} / \mathrm{mL})$, casein $(2 \%)$, HER2-ECD (0 (blank) and $50 \mathrm{ng} / \mathrm{mL})$, BSA $(0.5 \%), 3-\mathrm{IP}\left(1 \times 10^{-3} \mathrm{M}\right)$ and $\left.\mathrm{Ag}^{+}\left(4 \times 10^{-4} \mathrm{M}\right)\right)$.

We previously reported an immunosensor for HER2-ECD detection, using a gold nanoparticle-modified SPCE as transducer, but using $\mathrm{Ab}-\mathrm{C} 50 \mu \mathrm{g} / \mathrm{mL}$ and $\mathrm{Ab}-\mathrm{D} 1$ $\mu \mathrm{g} / \mathrm{mL} \underline{10}$. Comparing the results with the ones obtained in the present study, it can be concluded that lower $\mathrm{Ab}-\mathrm{C}$ concentrations (10 and $25 \mu \mathrm{g} / \mathrm{mL})$ and a higher $\mathrm{Ab}-\mathrm{D}$ concentration $(2 \mu \mathrm{g} / \mathrm{mL})$ lead to higher peak current intensities.

\subsubsection{Incubation Times and Enzyme Concentration}

The influence of the incubation time of the mixture HER2-ECD+Ab-D (containing $0.5 \%$ BSA) was studied using two different times: $30 \mathrm{~min}$ (A) and $60 \mathrm{~min}(\mathrm{~B})$. In addition, three concentrations of S-AP were tested: (1) $2 \times 10^{-10} \mathrm{M}$; (2) $5 \times 10^{-10} \mathrm{M}$ and (3) $1 \times 10^{-9} \mathrm{M}$, 
which were incubated for: $30 \mathrm{~min}$ (I) and $60 \mathrm{~min}$ (II). The influence of these parameters was studied using the previously optimized antibody concentrations (Ab-C $2 \mu \mathrm{g} / \mathrm{mL}$ and $\mathrm{Ab}-\mathrm{D} 2 \mu \mathrm{g} / \mathrm{mL}$ ). The different combinations between the incubation times of the mixture and the incubation time and concentrations of S-AP are shown in Figure 1 (b). The sequence of the tested parameters is presented according to the incubation time of the HER2-ECD+Ab-D mixture: I.1, II.1, II.2 and II.3 for A and I.1, I.2, I.3 and II.1 for B.

The results for the shortest incubation times combined with the lowest S-AP concentration (A - I.1) showed a considerable decrease of the peak current intensity. On the other hand, the longest incubation times combined with the lowest S-AP concentration (B - II.1) resulted in a considerable improvement of the electrochemical signal. Nevertheless, in the latter assay an increase of the blank signal was observed because of the increase of non-specific adsorption on the electrode surface. Regarding the assays in which longer incubation of the enzyme (II - $60 \mathrm{~min}$ ) was used higher signals were observed (A - II.1, A - II.2 and A - II.3), but an increase of the enzyme concentration increased the blank signal because of the adsorption of S-AP on the electrode's surface, indicating that a large amount of enzyme does not bind specifically to the Ab-D. This was also observed in B - I.3, although the enzyme incubation time was only $30 \mathrm{~min}$.

Thus, regardless of the analysis time, the increase of the S-AP concentration leads to higher signal intensity. The combination of the lowest S-AP concentration and incubation time (B - I.1) resulted in a higher analytical signal and a lower blank signal. As a compromise between sensitivity and analysis time assay A - II.2 was used in the subsequent studies.

In this work a higher analytical signal and a shorter assay time ( 2 h $20 \mathrm{~min}$ ) were obtained when compared to the previous work $\underline{10}$.

\subsubsection{Sensing Platform Modification and Characterization}

Distinct gold- and carbon-based nanomaterials can be used in the electrode surface modification procedure for HER2-ECD detection to obtain high sensitivities with reduced interferences and low detection limits $\underline{10}, \underline{11}, \underline{13}$. To compare the results obtained with SPCE-AuNPs as transducer, three carbon-based nanomaterials were tested: (i) rGO, (ii) SWCNT-COOH and (iii) MWCNT-COOH. In addition, the combination of rGO, SWCNT-COOH or MWCNT-COOH with AuNPs were also studied.

For the surface modification of the SPCEs the carbon nanomaterials' concentrations were optimized $(0.5 \mu \mathrm{g} / \mu \mathrm{L}, 1 \mu \mathrm{g} / \mu \mathrm{L}, 2 \mu \mathrm{g} / \mu \mathrm{L}$ and $4 \mu \mathrm{g} / \mu \mathrm{L})$ and $1 \mu \mathrm{g} / \mu \mathrm{L}$ was chosen because of the better sensitivity and precision of the analysis (data not shown).

The signals obtained using a 50-ng/mL HER2-ECD solution were compared with the ones obtained with the SPCE-AuNP (Figure 2). 


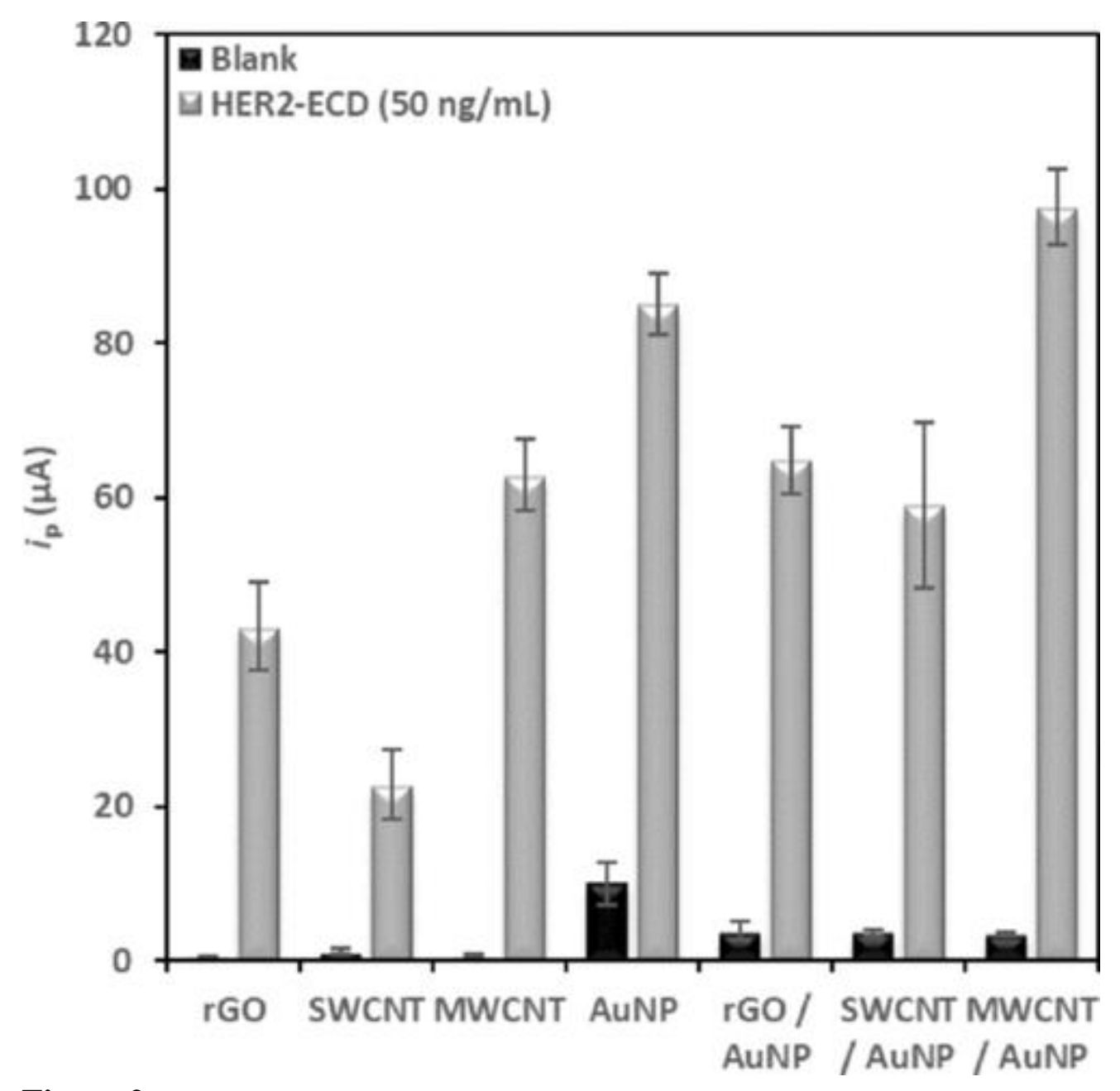

Figure 2

Peak current intensities obtained using the tested sensing platforms.

Between the distinct carbon nanomaterial types, either individually or combined with AuNPs, the use of MWCNTs led to the highest signal. However, only when the MWCNTAuNP combination was used an increase of the signal compared with the SPCE-AuNP was observed. Furthermore, the use of the carbon-based nanomaterials provided lower blank signals because coating the surface of the electrode with these materials is generally more effective, thereby reducing the interference of the sample matrix or the excess of antibodies and/or enzymes which have not been effectively removed in the washing step and which have no binding affinity to these materials. On the other hand, gold nanomaterials allow a more efficient immobilization of biomolecules, as can be observed by the increase of the signal.

Scanning electron microscopy (SEM) was used to characterize the modifications of the SPCE surfaces that provided the highest electrochemical signals. The electrodeposited AuNPs presented a normal distribution and a circular shape with an average diameter of $17.9 \pm 4.2 \mathrm{~nm}$ (Figure $\underline{3}(\mathrm{a})$ ). When the AuNPs were electrodeposited on the SPCE previously modified with carbon nanotubes an increase in their size was observed 
(average diameter: $26.1 \pm 5.6 \mathrm{~nm}$ ) because the surface of the SPCE was completely covered with the carbon nanotubes (Figure $\underline{3}(b)$ ).

(a)
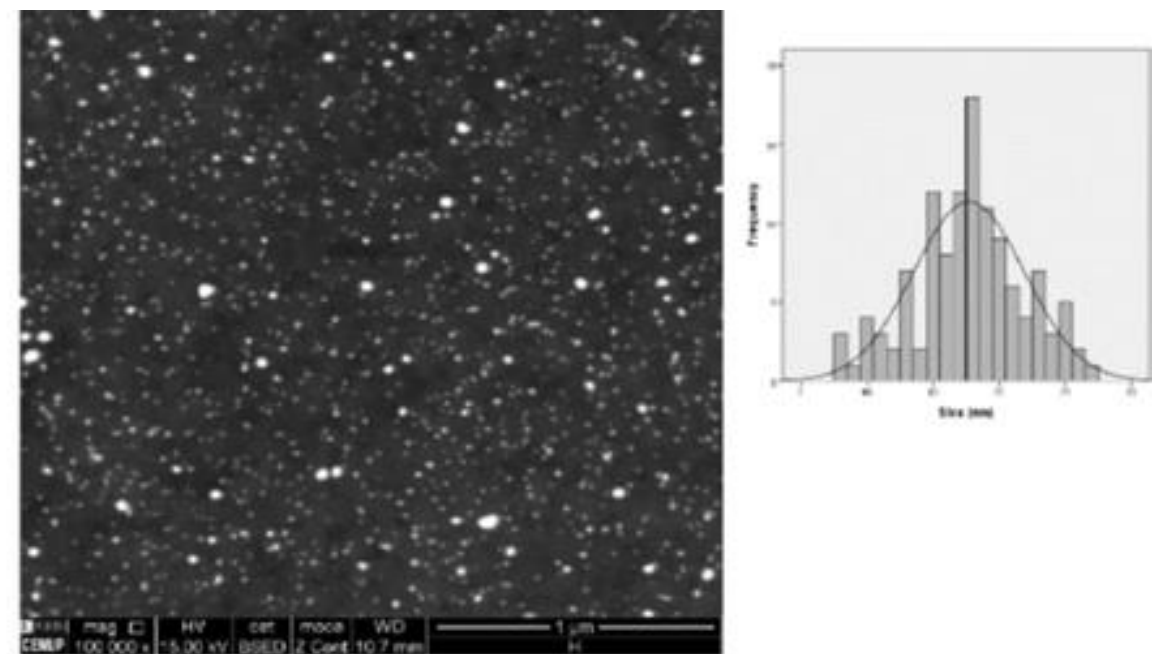

(b)
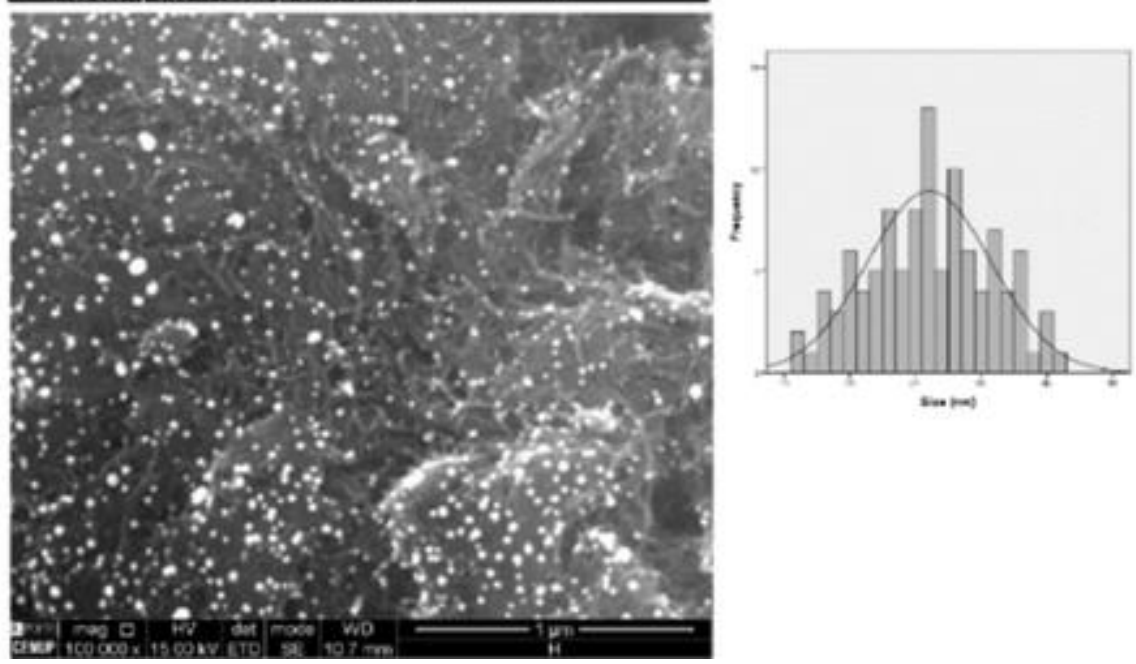

\section{Figure 3}

SEM images and respective histograms of (a) SPCE-AuNP and (b) SPCEMWCNT/AuNP.

\subsection{Analytical Performance and Applicability}

The analytical responses toward different HER2-ECD concentrations using the best surface modifications (AuNP and MWCNT/AuNP) were first tested in buffer. Solutions of HER2-ECD (concentrations between 7.5 and $100 \mathrm{ng} / \mathrm{mL}$ ) were analysed and the working ranges were established (data not shown). Then the sensing strategies were tested in spiked human serum samples. The linear relationship between $i_{p}$ and [HER2 ECD] $(7.5-50 \mathrm{ng} / \mathrm{mL})$ was established for SPCE-AuNP $(i \quad \mathrm{p}=1.22 \pm 0.07$ [HER2$\mathrm{ECD}]+27.6 \pm 2.1, \mathrm{r}=0.995)$ and for the SPCE-MWCNT/AuNP $(i \mathrm{p}=2.31 \pm 0.13$ [HER2$E C D]+9.03 \pm 4.27, r=0.997$. This shows that the SPCE-MWCNT/AuNP provided the highest sensitivity. The limits of detection (LOD) and quantification (LOQ) were calculated from the respective calibration plots using the equations: $\mathrm{LOD}=3 \mathrm{~s}$ blank $/ \mathrm{m}$ and $\mathrm{LOQ}=10 \mathrm{~s}$ blank $/ \mathrm{m}$ where $\mathrm{s}_{\text {blank }}$ is the standard deviation of the blank signal and $\mathrm{m}$ is the 
slope of the calibration plot. The LODs were $8.5 \mathrm{ng} / \mathrm{mL}$ for the SPCE-AuNP and 0.16 $\mathrm{ng} / \mathrm{mL}$ for the SPCE-MWCNT/AuNP. Considering the cut-off value for HER2-ECD (15 $\mathrm{ng} / \mathrm{mL}$ ), the sensing strategies provided LODs that were below this value, indicating their usefulness for HER2-ECD detection in the initial stage of the cancer. Representative voltammograms in the linear range and the calibration plots are presented in Figure 4 . Additional figures of merit are presented in Table $\underline{1}$.

(a)

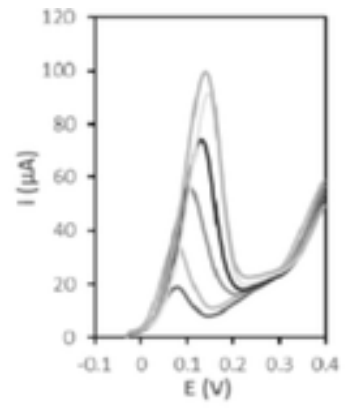

SPCE-AuNP

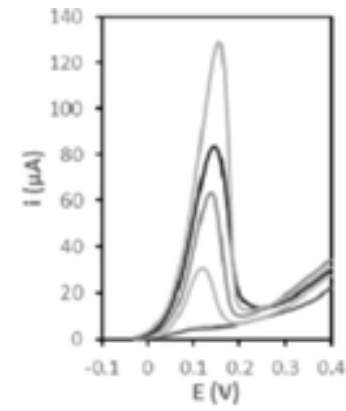

SPCE-MWCNT/AuNP

(b)

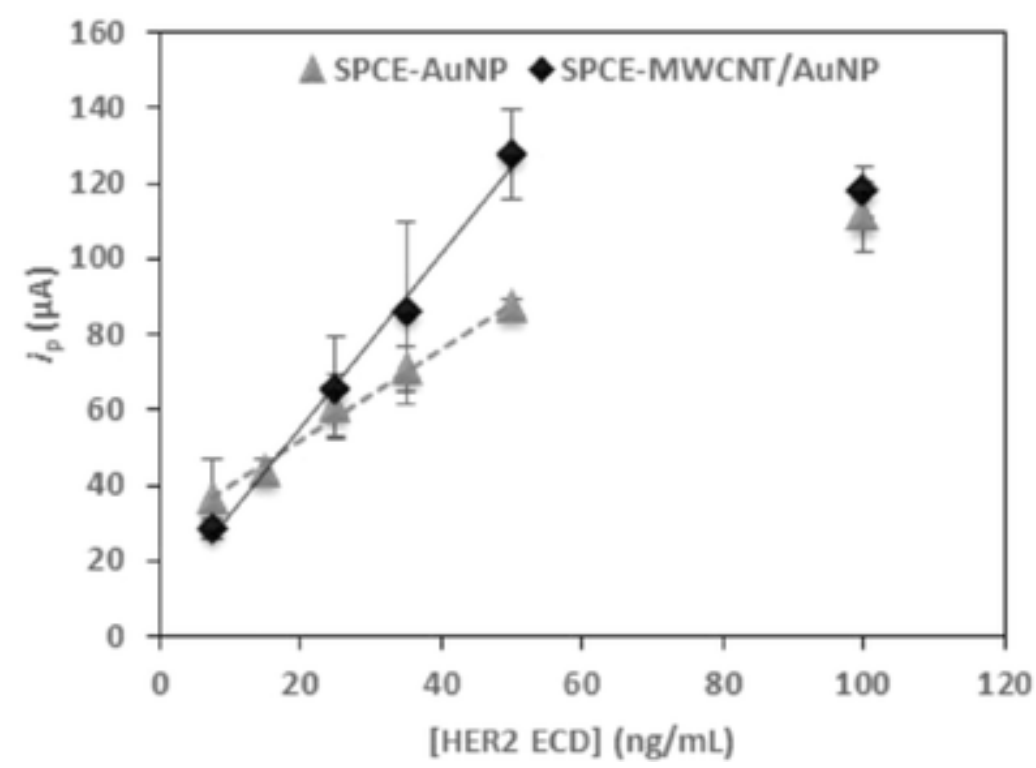

\section{Figure 4}

(a) Examples of linear sweep voltammograms for the analysis of HER2-ECD: 0, 7.5, 15, 25, 35 and $50 \mathrm{ng} / \mathrm{mL}$, (b) calibration plots in spiked human serum using SPCE-AuNP and SPCE-MWCNT/AuNP.

Table 1. Analytical characteristics of the developed electrochemical biosensors for the analysis of HER2-ECD in Human serum samples.

\begin{tabular}{l|ll} 
Figure of merit & $\begin{array}{l}\text { SPCE- } \\
\text { AuNP }\end{array}$ & $\begin{array}{l}\text { SPCE- } \\
\text { MWCNT/AuNP }\end{array}$ \\
\hline Concentration interval $(n g / m L)$ & $7.5-50$ & $7.5-50$ \\
Correlation coefficient $(r)$ & 0.995 & 0.997 \\
Slope $(m)(\mu \mathrm{A} /(\mathrm{ng} / \mathrm{mL})$ & 1.22 & 2.31
\end{tabular}




\begin{tabular}{l|ll}
$\begin{array}{l}\text { Standard deviation of the slope }\left(S_{m}\right) \\
(\mu \mathrm{A} /(\mathrm{ng} / \mathrm{mL})\end{array}$ & 0.07 & 0.13 \\
$\begin{array}{l}\text { Intercept }(b)(\mu \mathrm{A}) \\
\text { Standard deviation of the intercept }\left(S_{a}\right)(\mu \mathrm{A})\end{array}$ & 2.1 & \\
$\begin{array}{l}\text { Standard deviation of the linear regression } \\
\left(S_{y / x}\right)\end{array}$ & 2.30 & 4.63 \\
$\begin{array}{l}\text { Standard deviation of the method }\left(S_{x 0}\right) \\
\text { Coefficient of variation of the method }\left(V_{x 0}\right)\end{array}$ & 1.9 & 3.1 \\
$\begin{array}{l}(\%) \\
\text { Limit of detection }(L O D)(n g / m L)\end{array}$ & 8.5 & 1.7 \\
Limit of quantification $(L O Q)(n g / m L)$ & 28 & 5.8 \\
\end{tabular}

The precision of the results, in terms of repeatability and intermediate precision, using the distinct sensing platforms was tested by analysing a 50-ng/mL HER2-ECD solution in triplicate on the same day and different days. Relative standard deviations (RSD) of $2.8 \%$ and $6.5 \%$ for the SPCE-AuNP, $2.5 \%$ and $7.6 \%$ for the SPCE-MWCNT/AuNP were obtained, indicating that all the sensing platforms provided precise results.

Because the SPCE-MWCNT/AuNP provided the highest sensitivity, recovery studies with this platform were performed using spiked serum samples. The results for three replicates of added 7.5, 15 and $50 \mathrm{ng} / \mathrm{mL}$ HER2-ECD were found to be $8.25 \pm 0.67 \mathrm{ng} / \mathrm{mL}$, $12.4 \pm 0.98 \mathrm{ng} / \mathrm{mL}$ and $45.6 \pm 1.34 \mathrm{ng} / \mathrm{mL}$, with average recoveries of $110 \%, 83 \%$ and $91 \%$, respectively. These values indicated that the SPCE-MWCNT/AuNP provided accurate results.

The selectivities of the SPCE-AuNP and SPCE-MWCNT/AuNP were tested through the analysis of other biomarkers and possible serum interferents: another breast cancer biomarker (CA 15-3), a biomarker of kidney function (cystatin C) and human serum albumin (HSA). Solutions of these proteins of $30 \mathrm{U} / \mathrm{mL}$ (CA 15-3), $565 \mathrm{ng} / \mathrm{mL}$ (cystatin C) and $35 \mathrm{mg} / \mathrm{mL}$ (HSA) were tested. These concentrations were chosen based on the values that can be expected in real situations (except for CA 15-3, which can vary greatly in the case of cancer patients). The peak current intensities obtained for these non-target proteins are shown in Figure $\underline{5}$. As can be observed, the signals were significantly different from the ones obtained for HER2-ECD, confirming the selectivity of the different sensing platforms. 


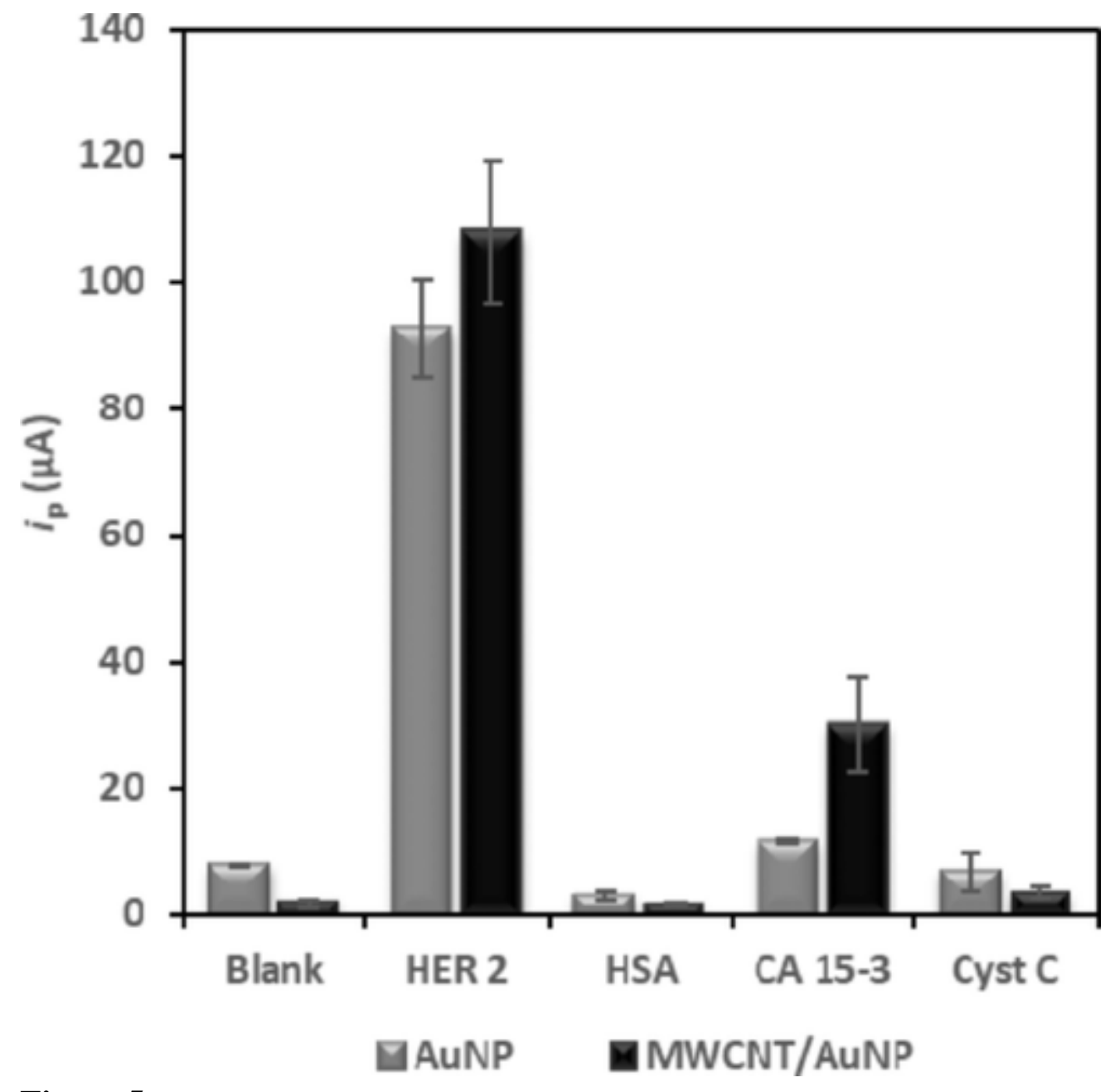

Figure 5

Results obtained in the selectivity studies using the developed sensing strategies.

In Table $\underline{2}$ some characteristics of electrochemical immunosensors and immunoassays reported for HER2 analysis in serum samples are presented. Although in label-free assays the analysis times are shorter than in the sandwich-type assays, the time required for the electrode surface modification and subsequent incubation of the capture antibody is considerably higher. From the comparison of the analytical performances of the immunomagnetic assays $\underline{14}-\underline{18}$ with the immunosensors $\underline{10}, \underline{11}, \underline{13}, \underline{19}$ can be concluded that when magnetic beads are used as sensing platform, shorter linear ranges and slightly lower LODs were obtained. This indicates that the use of magnetic particles and the detection strategy optimized in this work is promising. Nevertheless, all the reported sensing strategies provide limits of detection below the cut-off value for HER2 (15 $\mathrm{ng} / \mathrm{mL}$ ), which means that they could be useful in the clinical setting.

Table 2. Characteristics of electrochemical immunosensors and immunoassays for HER2 analysis. 


\begin{tabular}{|c|c|c|c|c|c|c|c|c|}
\hline $\begin{array}{l}\text { Transd } \\
\text { ucer }\end{array}$ & $\begin{array}{l}\text { Surface } \\
\text { modification }\end{array}$ & Assay & $\begin{array}{l}\text { Techniqu } \\
\text { e }\end{array}$ & Sample & $\begin{array}{l}\text { Assay } \\
\text { time }\end{array}$ & $\begin{array}{l}\text { Linear } \\
\text { range } \\
(\mathrm{ng} / \mathrm{m} \\
\mathrm{L})\end{array}$ & $\begin{array}{l}L O D \\
(n g / m \\
L)\end{array}$ & Ref. \\
\hline$S P C E$ & $\begin{array}{l}\text { AuNPs } \\
\text { MWCNT(-COOH) } \\
\text { /AuNPs }\end{array}$ & $\begin{array}{l}\text { Sandw } \\
\text { ich }\end{array}$ & LSV & $\begin{array}{l}\text { Spiked } \\
\text { human } \\
\text { serum }\end{array}$ & $\begin{array}{l}2 \\
\mathrm{~h} 20 \\
\min \end{array}$ & $7.5-50$ & $\begin{array}{l}8.5 \\
0.16\end{array}$ & This work \\
\hline$S P C E$ & AuNPs & $\begin{array}{l}\text { Sandw } \\
\text { ich }\end{array}$ & LSV & $\begin{array}{l}\text { Spiked } \\
\text { human } \\
\text { serum }\end{array}$ & $\begin{array}{l}2 \\
\text { h } 50 \\
\min \end{array}$ & $\begin{array}{l}15- \\
100\end{array}$ & 4.4 & $\underline{10}$ \\
\hline GSPE & AuNPs & $\begin{array}{l}\text { Label- } \\
\text { free }\end{array}$ & EIS & $\begin{array}{l}\text { Spiked } \\
\text { human } \\
\text { serum }\end{array}$ & $2 \mathrm{~h}$ & $5.0-40$ & 6.0 & $\underline{11}$ \\
\hline CILE & MWCNT/AuNPs & $\begin{array}{l}\text { Label- } \\
\text { free }\end{array}$ & EIS & $\begin{array}{l}\text { Patient } \\
\text { serum }\end{array}$ & $\begin{array}{l}35 \\
\min \end{array}$ & $\begin{array}{l}10- \\
110\end{array}$ & 7.4 & $\underline{13}$ \\
\hline$A u E$ & $\begin{array}{l}\mathrm{AuNP} / 3 \text { - } \\
\text { Mercaptopropionic } \\
\text { acid } \\
(\mathrm{MPA}) / \mathrm{Cysteamine} \\
/ \mathrm{Fe}_{3} \mathrm{O}_{4} \mathrm{NPs}\end{array}$ & $\begin{array}{l}\text { Label- } \\
\text { free }\end{array}$ & DPV & $\begin{array}{l}\text { Patient } \\
\text { serum }\end{array}$ & $\begin{array}{l}1 \\
\text { h } 15 \\
\min \end{array}$ & $\begin{array}{l}0.01- \\
1010- \\
100\end{array}$ & 0.995 & $\underline{14}$ \\
\hline$G C E$ & APTMS-Fe ${ }_{3} \mathrm{O}_{4}$ NPs & $\begin{array}{l}\text { Sandw } \\
\text { ich }\end{array}$ & DPV & $\begin{array}{l}\text { Spiked } \\
\text { human } \\
\text { serum }\end{array}$ & $\begin{array}{l}1 \\
\text { h } 50 \\
\min \end{array}$ & $\begin{array}{l}5.0 \times 10 \\
-4-50\end{array}$ & $\begin{array}{l}2.0 \times 1 \\
0^{-5}\end{array}$ & $\underline{15}$ \\
\hline$S P C E$ & $\begin{array}{l}\text { Protein A-MBs } \\
\text { (ProtA-MBs) }\end{array}$ & $\begin{array}{l}\text { Sandw } \\
\text { ich }\end{array}$ & DPV & $\begin{array}{l}\text { Patient } \\
\text { serum }\end{array}$ & $\begin{array}{l}2 \\
\text { h } 05 \\
\min \end{array}$ & $2.5-15$ & 6.0 & $\underline{16}$ \\
\hline $8 \times S P E$ & $\begin{array}{l}\text { Protein A-MBs } \\
\text { (ProtA-MBs) } \\
\text { Streptavidin MBs } \\
\text { (Strep-MBs) }\end{array}$ & $\begin{array}{l}\text { Sandw } \\
\text { ich }\end{array}$ & DPV & $\begin{array}{l}\text { Spiked } \\
\text { human } \\
\text { serum }\end{array}$ & $\begin{array}{l}1 \\
\text { h } 51 \\
\min 2 \\
\text { h } 51 \\
\text { min }\end{array}$ & $2.5-20$ & $\begin{array}{l}2.6 \\
3.4\end{array}$ & $\underline{17}$ \\
\hline$S P C E$ & $\begin{array}{l}\text { Carboxylic acid- } \\
\text { modified } \\
\text { MBs(HOOC-MBs) }\end{array}$ & $\begin{array}{l}\text { Sandw } \\
\text { ich }\end{array}$ & $\begin{array}{l}\text { Amperom } \\
\text { etry }\end{array}$ & $\begin{array}{l}\text { Human } \\
\text { serum } \\
\text { and cell } \\
\text { lysates }\end{array}$ & $2 \mathrm{~h}$ & $0.1-32$ & $\begin{array}{l}26 \times 10 \\
-3\end{array}$ & $\underline{18}$ \\
\hline$S P E$ & - & $\begin{array}{l}\text { Sandw } \\
\text { ich }\end{array}$ & $\mathrm{CV}$ & $\begin{array}{l}\text { Patient } \\
\text { serum }\end{array}$ & $\begin{array}{l}6 \\
\text { h } 05 \\
\min \end{array}$ & $\begin{array}{l}5.0-20 \\
20- \\
200\end{array}$ & 4.0 & $\underline{19}$ \\
\hline
\end{tabular}

In the strategies studied in our work generally similar linear ranges and analysis times were obtained and the LODs were comparable with the ones reported in the previous works, except for the studies in which magnetic particles were applied. Nevertheless, the best sensitivity was obtained for the SPCE-MWCNT/AuNP which is probably due to the 
good electrode surface coverage of the carboxylic acid functionalized MWCNTs and subsequent electrodeposition of gold, which allows suitable antibody immobilization.

\section{Conclusions}

To improve the electrochemical analysis of HER2-ECD, the modification of the surface of SPCEs with gold (AuNPs) and carbon nanomaterials (rGO, SWCNT-COOH and MWCNT-COOH) and combinations of these materials were tested. Among the carbonbased nanomaterials, MWCNT-COOH provided the highest sensitivity. The combination of MWCNT-COOH with AuNPs revealed the highest sensitivity. The antibody concentrations were optimized and used to develop biosensing strategies on SPCE-AuNP and SPCE-MWCNT/AuNP, achieving limits of detection well below the cut-off value for this breast cancer biomarker.

Spiked human serum samples were used to test the sensing platforms' applicability and the selectivity was confirmed through the analysis of other biomarkers and possible serum interferents: Human Serum Albumin (HSA), Cancer Antigen 15-3 (CA 15-3) and Cystatin $\mathrm{C}$, observing no significant interference of these proteins in the analysis.

Like this, the developed sensing strategies could be an alternative for the analysis of HER2-ECD.

\section{Acknowledgements}

Maria Freitas is grateful to FCT-Fundação para a Ciência e a Tecnologia for her $\mathrm{PhD}$ grant (SFRH/BD/111942/2015), financed by POPH-QREN-Tipologia 4.1-Formação Avançada, subsidized by Fundo Social Europeu and Ministério da Ciência, Tecnologia e Ensino Superior. This work received financial support from the European Union (FEDER funds through COMPETE) and National Funds (FCT) through project UID/QUI/50006/2013.

\section{References}

- 1J. Ferlay, I. Soerjomataram, R. Dikshit, S. Eser, C. Mathers, M. Rebelo, D. M. Parkin, D. Forman, F. Bray, Int. J. Cancer. 2015, 136, E 359-E 386.

- 2A. Ravelli, J. M. Reuben, F. Lanza, S. Anfossi, M. R. Cappelletti, L. Zanotti, A. Gobbi, C. Senti, P. Brambilla, M. Milani, D. Spada, P. Pedrazzoli, M. Martino, A. Bottini, D. Generali, Tumor Biol. 2015, 36, 6653- 6665. 
- 3A. M. Berghuis, H. Koffijberg, J. Prakash, L. W. Terstappen, M. J. IJzerman, Int. J. Mol. Sci. 2017, 18, 363- 408.

- $\quad$ 4S. Campuzano, M. Pedrero, J. M. Pingarrón, Sensors 2017, 17, 1993- 2016.

- 5M. Freitas, H. P. A. Nouws, C. Delerue-Matos, Electroanalysis 2018, 30, 1- 21.

- 6Biomarkers Definitions Working Group, Clin. Pharmacol. Ther. 2001, 69, 8995.

- 7S. Mittal, H. Kaur, N. Gautam, A. N. Mantha, Biosens. Bioelectron. 2017, 15, 217-231.

- 8M. Hasanzadeh, N. Shadjou, M. de la Guardia, TrAC Trends Anal. Chem. 2017, 91, 67- 76 .

- 9A. Mishra, M. Verma, Cancers 2010, 2, 190- 208.

$\underline{\text { Crossref }} \underline{\text { CAS }} \underline{\text { PubMed Google ScholarTexto Integral @ b-on }}$

- 10R. C.B Marques, S. Viswanathan, H. P. A. Nouws, C. Delerue-Matos, M. B. González-García, Talanta 2014, 129, 594- 599.

- 11A. Ravalli, C. G. Rocha, H. Yamanaka, G. Marrazza, Bioelectrochemistry 2015, 106, 268- 275.

- $\quad$ 12B. Wang, U. Akiba, J. I. Anzai, Molecules 2017, 22, 1048- 1068. 
- 13E. Arkan, R. Saber, Z. Karimi, M. Shamsipur, Anal. Chim. Acta 2015, 874, 6674.

- 14M. Emami, M. Shamsipur, R. Saber, R. Irajirad, Analyst 2014, 139, 2858- 66.

- 15M. Shamsipur, M. Emami, L. Farzin, R. Saber, Biosens. Bioelectron. 2018, 103, $54-61$.

- 16Q. A. M. Al-Khafaji, M. Harris, S. Tombelli, S. Laschi, A. P. F. Turner, M. Mascini, G. Marrazza, Electroanalysis 2012, 24, 735- 742.

- $\quad$ 17H. Ilkhani, A. Ravalli, G. Marrazza, Chemosensors 2016, 4, 1- 10.

- $\quad$ 18U. Eletxigerra, J. Martinez-Perdiguero, S. Merino, R. Barderas, R. M. TorrenteRodríguez, R. Villalonga, J. M. Pingarrón, S. Campuzano, Biosens. Bioelectron. 2015, 70, 34- 41 .

- 19S. D. Tallapragada, K. Layek, R. Mukherjee, K. K. Mistry, M. Ghosh, Bioelectrochemistry 2017, 118, 25-30.

- 20G. Martínez-Paredes, M. B. González-García, A. Costa-García, Electrochim. Acta 2009, 54, 4801-4808. 